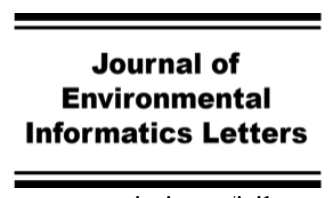

www.iseis.org/jeil

\title{
An Analysis of Selected Oil Spill Case Studies on the Shorelines of Canada
}

\author{
Q. Feng ${ }^{1}$, C. J. An ${ }^{1}$, Y. Cao ${ }^{1}$, Z. Chen ${ }^{1}$, E. Owens ${ }^{2}$, E. Taylor ${ }^{3}$, Z. Wang ${ }^{1}$, and E. A. Saad ${ }^{1}$ \\ ${ }^{1}$ Department of Building, Civil and Environmental Engineering, Concordia University, Montreal, QC H3G 1M8, Canada \\ ${ }^{2}$ Owens Coastal Consultants, Bainbridge Island, WA 98110, United States \\ ${ }^{3}$ Polaris Applied Sciences Inc., Bainbridge Island, WA 98110, United States
}

Received 06 February 2021; revised 26 February 2021; accepted 12 March 2021; published online 04 April 2021

\begin{abstract}
After an oil spill, oil may wash ashore and there is only a short window of opportunity to respond. Analysis of historical incident data is valuable to guide future responses and cleanup practices. This study summarized the oil spill accidents that impacted the Canadian shoreline and analyzed the related information including location, incident characteristics, and shoreline treatment. Major spills due to tanker accidents in Canadian marine waters fortunately have been infrequent. Most of the accidents have happened on Canada's Pacific coast, accounting for $52 \%$ of the total accidents recorded. The Atlantic coast accounted for $39 \%$ and the remaining accidents happened in the Arctic region. Regarding spilled volume, 55\% of the accidents spilled oil volumes smaller than $100 \mathrm{~m}^{3}$. Spilled volumes between $100 \sim 1000 \mathrm{~m}^{3}$ represent $30 \%$ of the incidents and $15 \%$ had spilled volume greater than $1000 \mathrm{~m}^{3}$. Bunker C fuel and diesel were the main types of the spilled oil, accounting for 33\% of the spills, respectively. Within the oil spill accidents impacting Canadian shorelines, marine vessel accidents were the major sources accounting for $70 \%$ of the spill accidents. In terms of the shoreline treatment, the commonly employed treatments were manual, vacuum, mechanical, and sorbent removal. The dataset highlighted the significance of a more comprehensive record for response phase details and environmental effects monitoring.
\end{abstract}

Keywords: oil spill, shoreline, case studies, cleanup, Canada

\section{Introduction}

Oil spills result from natural seeps and anthropogenic activities, including terrestrial run-off, drilling platforms, routine operations, transportation, and pipeline spills (National Research Council, 2003). Increasing energy demand and economic development lead to continuous gas and oil exploration, refined oil production, and traffic in zones with potential oil sources, which notably raise the risk of oil spill accidents in specific areas (Lee and Jung, 2013). Oil spilled onto marine waters may be driven shoreward and reach shorelines within hours or days depending on the spill location along with weather and current conditions. Therefore, the time available for implementing shoreline protection strategies following an oil spill may be short (Environment and Climate Change Canada, 2016).

The coastal area is unique with regard to oil fate and behavior and cleanup practices. The population density in coastal areas is double that of inland areas, and one-third of the global population reside in coastal communities (Barbier et al., 2008). The coastal areas feature a wide variety of ecosystems and habitats. It is well recognized that coastal ecosystems serve an essential role in enhancing the well-being of humans (Liquete et al., 2013). Thus, sustaining the continuous fluxes of benefits is

${ }^{*}$ Corresponding author. Tel.: +1(514) 848-2424 ext. 7857.

E-mail address: chunjiang.an @ concordia.ca (C. J. An).

ISSN: 2663-6859 print/2663-6867 online

(C) 2021 ISEIS All rights reserved. doi:10.3808/jeil.202100052 deemed as one of the most important factors for the sustainable management of coastal areas.

The treatment of oiled shoreline depends on the shorezone character and the properties of the spilled oil (IPIECA, 2016). Persistent oil may attenuate slowly so that environmental recovery may be a slow process. Experience has shown that inappropriate cleanup tactics may delay recovery. The consequences and effectiveness of shoreline treatment are primarily decided by the method employed and the operation scale. For instance, trampling and utilization of heavy machines and vehicles in marshes, mangroves, and soft sediments can lead to physical damage, such as sediment compaction and root destruction (NOAA, 2013). Trampling can cause oil to penetrate subsurface sediments and thus prolong oil persistence. The aggressive cleanup of the Ile Grande marshes following the 1978 Amoco Cadiz spill gave rise to long-term physical disturbances and erosion, whereas oiled but uncleaned marshes recovered more rapidly (Gilfillan, 1995). Delayed recovery of estuarine marshes due to excessive trampling was also recorded following the cleanup activities after the 2006 Westwood Anette spill in British Columbia (Challenger et al., 2008). Therefore, it is important to learn from these previous experiences including the planning, techniques, and potential consequences of oil spill cleanup activities.

In the past years, there has been an increasing need for better conservation and monitoring of coastal areas. In Canada, Environment and Climate Change Canada's (ECCC) Environ- 
mental Emergencies Branch is responsible for tracking cleanups and providing advice to responsible parties. ECCC relies on experience from prior spills and shoreline sensitivity maps. The analysis of pre-spill data is important for determining the causes, failure characteristics, related impacts, and statistical trends (Cunha et al., 2015). This facilitates a better awareness of accident mechanisms and assists in the preparation of protection and treatment measures. Thus, the objective of the present study was to compile and analyze existing information on oil spill accidents that reached the Canadian shorelines. This data is used in the Shoreline Response Program (SRP) Decision Support Tool (DST) as a similarity component for the MultiPartner Research Initiative (MPRI) (Owens et al., 2021).

\section{Methods}

Oil spill accidents and related information were searched and screened from websites of public and private organizations, official organization reports, project reports, peer-reviewed articles, and other databases (Table 1). Spills included in the present dataset were those that reached the Canadian shorelines. Relevant information for each case was also collected. The dataset was examined to exclude cases not fitting the requirements. Location information (longitude, latitude, province, site, and time), accident characteristics (accident type, accident description, spilled oil type, volume spilled, volume on shoreline, and oiled shoreline length), facility owner, country of the owner, shoreline information (shoreline substrate type and shoreline treatment method), and waste data were gathered, if available, for further analysis. Missing data of each spill accident were completed by reviewing the available information in the accident description or by referring to the available spill location map. Missing geographic coordinates were obtained approximately by referring to site descriptions when available.

\section{Results and Discussion}

\subsection{Spill Case Studies}

The number of case studies that were used in this study is graphed by decade in Figure 1 (excluding experimental oil spills). Major spills due to tanker accidents in Canadian marine waters fortunately have been infrequent. The largest marine oil spill in Canadian history, and the sixth largest worldwide, was the 132,000 tonnes released in October 1988 from the T/V Odyssey $1,300 \mathrm{~km}$ off the coast of Nova Scotia, a spill more than four time larger than the T/V Exxon Valdez but with no shoreline impacts (ITOPF, 2018). The three largest marine spills in Canadian waters that affected the shoreline were all on the Atlantic Coast in the 1970s; Arrow (approximately 11,000 $\mathrm{m}^{3}$ ); Kurdistan (approximately 7,700 $\mathrm{m}^{3}$ ), and the barge Irving Whale (approximately 1,210 $\mathrm{m}^{3}$ ). A land spill from a tank farm at Deception Bay, on Hudson Strait, released approximately 1,612 $\mathrm{m}^{3}$ of light fuel products that oiled the adjacent shoreline in 1970. The largest on the Pacific Coast was from the barge Nestucca $\left(874 \mathrm{~m}^{3}\right)$ which grounded in Washington State in late 1988 but oiled some of the southwestern and western shores of Vancouver Island in early 1989.

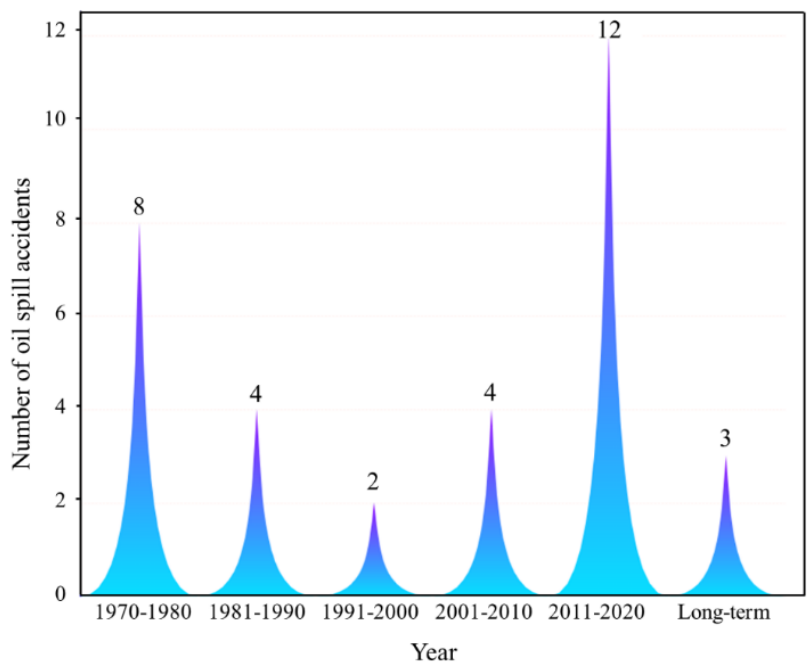

Figure 1. Numbers of oil spill accidents reviewed from 1970 to the present.

The T/V Arrow had a cargo of $11,000 \mathrm{~m}^{3}$ of Bunker $\mathrm{C}$ fuel and ran aground on Cerberus Rock at the entrance to the Strait of Canso during a storm in February 1970, spilling almost the entire cargo into Chedabucto Bay and resulting in an estimated $305 \mathrm{~km}$ of oiled shorelines (Owens, 2010a). The "Arrow" spill was unusual in one respect as part of the oiled shoreline at Black Duck Cove deliberately remained uncleaned to allow for the long-term scientific assessment of natural attenuation processes (Owens, 1971; Owens et al., 1993, 2008; Owens, 2010a; Lee et al., 2020). Another major spill occurred when the T/V Kurdistan broke into two sections in 1979 and spilled 7,700 $\mathrm{m}^{3}$ of Bunker C fuel into Cabot Strait. Overall, more than $880 \mathrm{~km}$ of shoreline were in the affected area after this spill although only small fraction required cleanup, in part because of the presence of shore-zone ice that protected many sections of coast in the period following the release (Duerden and Swiss, 1981; Kienholz et al., 1982; Taylor and Frobel, 1985). The tank barge "Irving Whale" sank off the north coast of Prince Edward Island in 1970 and approximately $1,210 \mathrm{~m}^{3}$ of bunker $\mathrm{C}$ fuel reached the Magdalen Islands and oiled $80 \mathrm{~km}$ of shoreline (Ages, 1971). Oil from the sunken barge was associated with tarballs that were found on shorelines of the Magdalen Islands in subsequent years until the barge was refloated in 1996 (Brown et al., 1996). A release from the sunken "Arrow", in 2015, resulted in a limited second shoreline oiling event (Owens et al., 2017).

\subsection{Spill Location}

The majority of the case studies of spills that affected marine shorelines occurred on Canada's Pacific coast, accounting for $52 \%$ of the total accidents that we reviewed. The Atlantic coast accounted for $39 \%$ of the accidents, and the remainder were in the Arctic region (Figure 3). By volume, the top three exports and imports of Canada are crude oil, coal, and iron ore (Council of Canadian Academies, 2017). The vast proportion of marine commerce in crude oil occurs in Atlantic Canada, although Alberta leads crude oil production, accounting for 
Table 1. Data Sources

\begin{tabular}{llll}
\hline Institutions & Geographical range & Spill types included & Starting date \\
\hline $\begin{array}{l}\text { International Tanker Owners Pollution Federation } \\
\text { (ITOPF) }\end{array}$ & Global & $\begin{array}{l}\text { Oil, Hazardous, noxious } \\
\text { substances } \\
\text { Oil, Hazardous, noxious } \\
\text { substances }\end{array}$ & 1979 \\
$\begin{array}{l}\text { France's Centre for Documentation, Research and } \\
\text { (Cedre) }\end{array}$ & Global & Oil & 1917 \\
$\begin{array}{l}\text { National Oceanic and Atmospheric Administration } \\
\text { (NOAA), Incident News }\end{array}$ & Global & Oil & 1957 \\
$\begin{array}{l}\text { Arctic and Marine Oil Spill Program Technical } \\
\text { Seminar (AMOP) }\end{array}$ & Arctic & Canada & Oil, Hazardous and noxious \\
$\begin{array}{l}\text { Government of Northwest Territories, } \\
\text { Environment and natural resources }\end{array}$ & substances, Waste & 1948 \\
$\begin{array}{l}\text { Fisheries and Oceans Canada Library } \\
\text { Government of British Columbia, Past spill }\end{array}$ & Canada & British Columbia, Canada \\
incidents & Oil, Hazardous and noxious \\
\hline
\end{tabular}

$80.5 \%$ of Canada's total production. The reason for this is that most crude oil exports are transferred by pipeline from Alberta to the United States, whereas the vast majority of marine commerce in crude oil occurs in Atlantic Canada (Council of Canadian Academies, 2017). Because of a lack of road or rail access, marine shipping is a crucial means for communities in the Canadian Arctic to obtain essential goods, such as food, fuel, and construction materials, and to connect the community to North American commerce (Council of Canadian Academies, 2017). In British Columbia, Vancouver is the biggest port for domestic ocean trade, primarily associated with forest products and minerals.

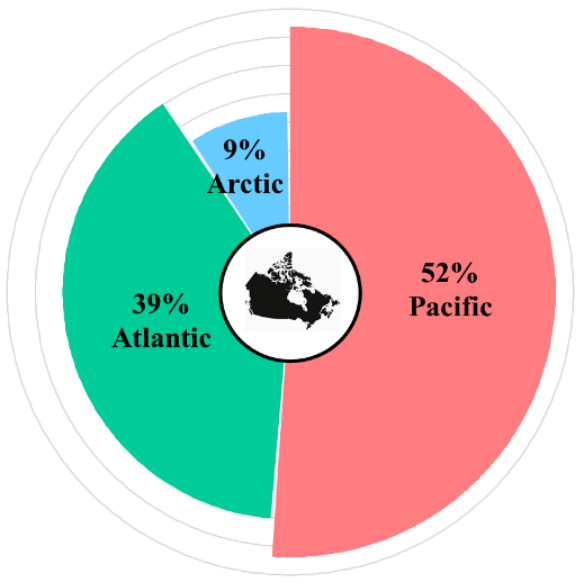

Figure 2. Regions of oil spill accidents.

\subsection{Spilled Oil Type and Volume}

Bunker $\mathrm{C}$ fuel and diesel were the main types of the spilled oil in the case studies, both accounting for $33 \%$ of the spills. Crude oil accounted for $18 \%$. Other oil types, and unidentified types, accounted for a small proportion (Figure 3). Except for cases with unidentified spilled volumes, $30 \%$ of the accidental spill oil volumes were smaller than $10 \mathrm{~m}^{3}$. Spilled volumes between $10 \sim 100 \mathrm{~m}^{3}$ accounted for $25 \%$, and volumes between $100 \sim 1000 \mathrm{~m}^{3}$ accounted for $30 \%$. The remaining $15 \%$ of the accidents had spilled volumes greater than $1,000 \mathrm{~m}^{3}$. As noted above the Arrow incident followed by the Kurdistan, Deception Bay, and Irving Whale oil spills, are the top four oil spill accidents, by volume, that affected shorelines in our dataset and all occurred in the 1970s. As can be seen in Figure 4, all four of these spills larger than $1,000 \mathrm{~m}^{3}$ occurred in the Atlantic region.

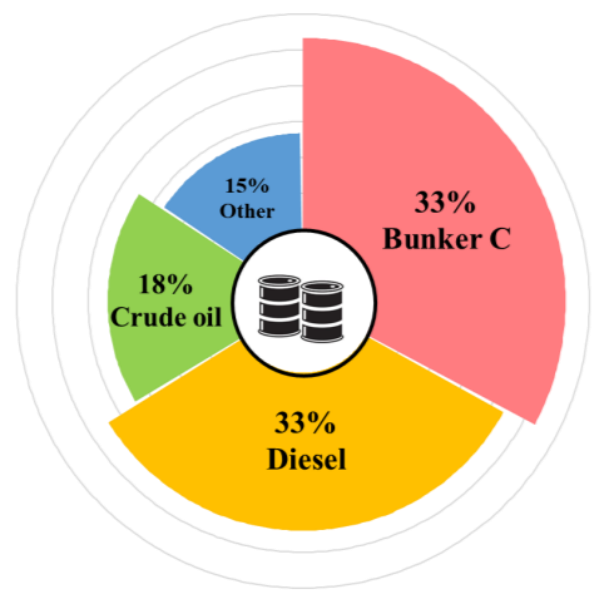

Figure 3. Spilled oil types.

\subsection{Accident Type}

Within the dataset of oil spill accidents impacting Canadian shorelines, marine vessel accidents were the major sources accounting for $70 \%$, followed by land spills to the marine environment and experimental spills (Figure 5). Spill on land can impact shorelines. Canada has more than $840,000 \mathrm{~km}$ of pipelines, most of which are concentrated in the western part of Canada (Government of Canada, 2020). The 2007 Westridge spill, caused by a pipeline rupture in Burnaby, British Columbia, spilled $224 \mathrm{~m}^{3}$ of heavy synthetic crude oil blend of which a portion reach Burrard Inlet (Trans Mountain, 2007). In 2014, a pipeline spilled $100 \mathrm{~m}^{3}$ of diesel to the water at the port of Cap-aux-Meules, Quebec (La Presse, 2014). In 2018, a broken pipe of Tufts Cove generating plant spilled $24 \mathrm{~m}^{3}$ of bunker C fuel on shore and into the Halifax harbor (Bradley, 2018). 


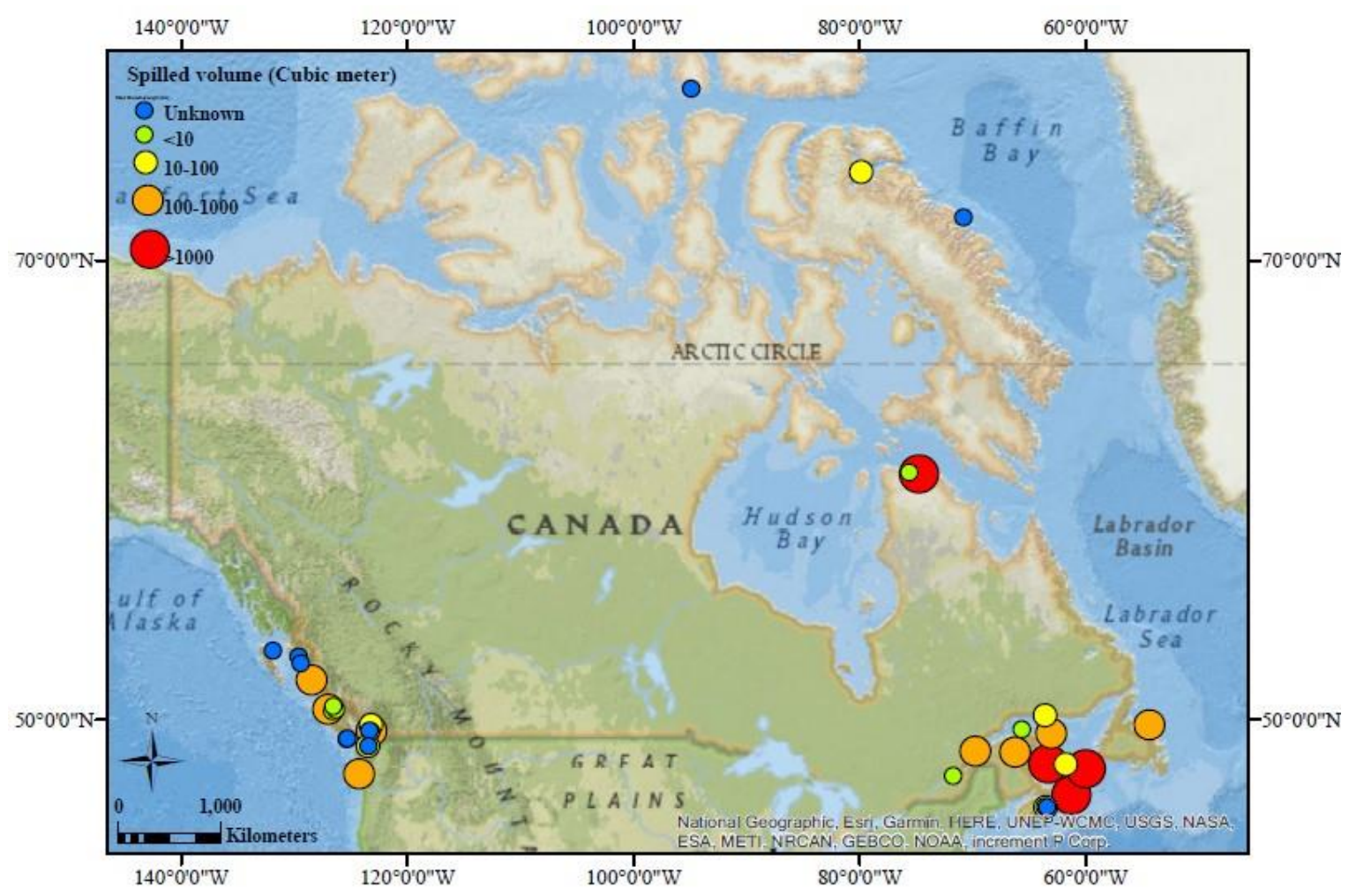

Figure 4. Spilled volume of each oil spill accident.

Leaking tanks close to shore may also cause damage to shoreline. In Kelsey Bay, British Columbia, a diesel tank nearshore spilled diesel due to a small pinhole on the bottom of the tank (BC government, 2017). In 1970, a tank farm in the Deception Bay, Quebec spilled about $1,389 \mathrm{~m}^{3}$ of diesel and $223 \mathrm{~m}^{3}$ of gasoline on shore (Ramseier, 1973).

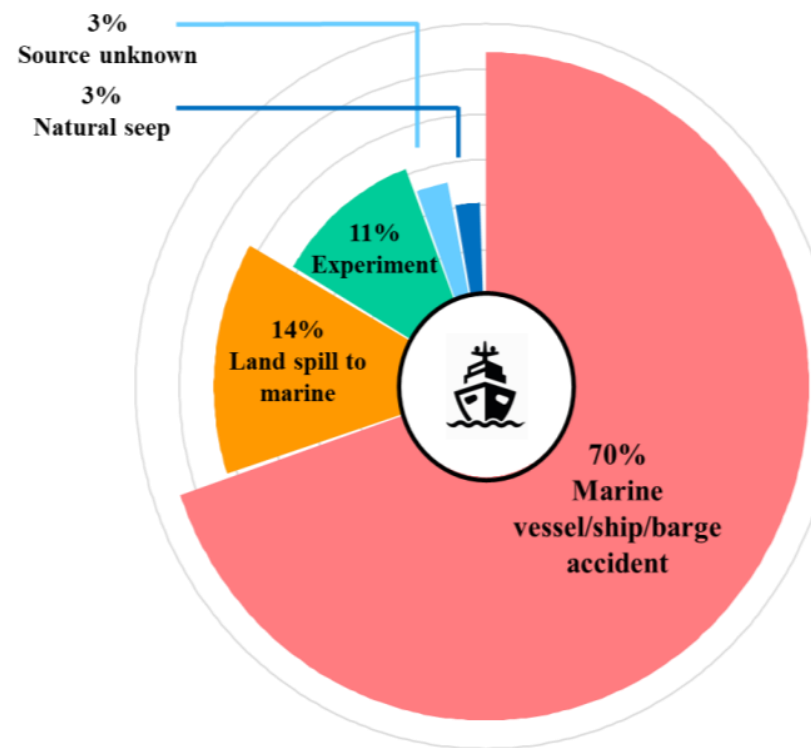

Figure 5. Accident types of oil spill accidents.

\subsection{Shoreline Oiling and Treatment}

If natural attenuation of stranded oil is not an acceptable option there are three types of strategies for oil spill treatment, or cleanup: physical removal, in situ treatment, and chemical or biological treatment (Environment and Climate Change Canada, 2016). Although there are a range of cleanup techniques, the most commonly employed options in past oil spills have been manual removal, vacuums, mechanical removal, and sorbents. Few of the case studies on oiled shoreline treatment in Canada describe the actual strategies or tactics that were used in any detail. Four exceptions are the Arrow, Kurdistan, Westwood Annette, and Westridge response operations. After the 1970 "Arrow" oil spill, beach cleaning methods were primarily mechanical removal using front-end loaders (Owens, 1971) The basic tactic was to clean selected beaches between the low and high water levels to prevent tides from lifting oil from one beach and carrying it to another. Importantly, the detailed records generated by the Department of Public Works document waste removal volumes on a beach-by-beach basis which provide valuable data on waste generated by manual and mechanical removal methods (Owens et al., 2009). Oil on some beaches was treated with peat moss, straw, and dry sawdust, and other absorbents were also applied to test the potential to improve the efficiency of oil removal. Piers were cleaned with high-pressure heated water (The Ministry of Transport, 1970). The "oleovator" or "slick-licker", a conveyor belt apparatus that mechanically recovered oil in inlets and near the beach, was developed by the Canadian Defense Research Establishment (Pacific) and con- 
ceivably was the first use of a skimmer on an oil spill response (The Ministry of Transport, 1970). Much of the oil was accessible only for manual removal with rakes and shovels, a slow and difficult tactic on many of the coarse sediment or bedrock shores (Owens et al., 1993; Owens, 2010b; Lee et al., 2020).

For the "Kurdistan" response, which occurred at a time when nearshore and shore-zone ice was present, the Canadian Coast Guard mounted backhoe loaders, floating booms, and sorbents onto a barge. They tried to remove the oil from the water using the loaders. However, the surface area affected by the slick was too large for this method to be efficient. Eventually, cleanup teams removed the oil as it reached the shore using rakes, shovels, and forks. The viscosity of fuel oil in cold water allowed it to be readily removed and collected in plastic sacks. Shoreline cleanup was carried out by 500 people (Duerden and Swiss, 1981; Kienholz et al., 1982).

The 2007 Westridge oil spill leaked $224 \mathrm{~m}^{3}$ of heavy synthetic crude oil blend, of which approximately $40 \%$ of the oil entered the storm drain system and reached Burrard Inlet through shoreline storm outfalls, a submerged storm outfall, and Kask Creek. Booming was deployed to constrain oil around the release points. Exclusion booming was deployed to protect sensitive shorelines. Skimmers and sorbent pads were utilized to remove oil. Tar balls and oily debris were manually removed (Trans Mountain, 2007).

Manual removal is suitable for small volumes of viscous oil, surface oil, and areas unreachable to machines or where machines cannot be operated. When large numbers of workers are required to complete the cleanup objectives, excessive foot traffic can damage plants or push oil into subsurface layers in tidal flats, marshes, backshore dunes, or disturb adjacent resources. Vacuuming is aimed at removing oil by suction from oil pools. It is a labor-intensive technique and is not safe to apply to volatile oil. Mechanical removal can be applied on many types of shorelines, except for solid manmade and bedrock substrates. The feasibility of different cleanup machines depends on the weight-bearing capacity of the substrates and the gradient of the shore zone, as well as the performance of the individual equipment. Sorbents can be applied to various types of substrate and small volumes of spilled oil, but they are not effective for the treatment of solid oil, and less efficient for heavy viscous oils relative to medium crudes. They must be substituted frequently, even when applied for the treatment of small amounts of oil. The method is labor-intensive and can produce large amounts of oily waste. Sorbents are generally used as a follow-up procedure to remove residue oil or in inaccessible areas (Environment and Climate Change Canada, 2016).

\subsection{Biological and Social-Economical Implications}

Coastal oil spills pose threats to biological and socio-economical features and reduce ecosystem services delivery, including fisheries and aquaculture industries, tourism, plants, sea birds, and marine mammals. After the 1988 Nestucca barge oil spill, about 56,000 seabirds died; in addition, many crabs and shellfish were oiled. Fisheries were also impacted due to shoreline oiling (BC government, 1988). Following the Kur- distan spill although the number of oiled birds could not be accurately assessed it is estimated that as many as $80 \%$ might have died at sea without their bodies being found (Duerden and Swiss, 1981). Nonetheless, according to the estimation of the Canadian Wildlife Service, the number of dead birds was approximated as 12,000 25,000, seal mortality was also recorded (Duerden and Swiss, 1981). The Irving Whale spill resulted in the deaths of at least 5,500 birds around the southern coast of Newfoundland (NOAA, 1970). Birds can become oiled when they dive to feed or swim on the water surface if they are within an oil slick. Feathers insulate birds and when oiled this insulation is lost and the bird is subject to hypothermia. Birds can also ingest oil when they preen themselves to clean their feathers (Morandin and O'Hara, 2016).

Fur-bearing marine mammals are highly vulnerable to spilled oil. Marine mammals, such as seals, sea otters, or sea lions, are especially at risk when their haulouts or rookery areas are oiled. The animals may inhale toxic oil fumes, and their eyes or skins may be irritated by oil (Helm et al., 2015). Shorelines are also characterized by distinctive ecosystems. Salt marshes, wetlands, and estuaries are recognized as economic and biological resources with some highly beneficial ecosystem services and are the most vulnerable habitats when the released oil arrives at the shoreline (Venosa et al., 2002).

Oil residue in shoreline sediments is often assessed to reveal the spatial distribution, sources, and occurrence of petroleum-related hydrocarbons (Wang et al., 2020). Changes in chemical components and biodegradation are both crucial factors examined in weathering assessments. Partial loss of n-alkanes is usually found in lightly degraded oil. Moderately degraded oil is generally denoted by heavy depletion of n-alkanes and partial depletion of lighter PAH compounds. In terms of highly degraded oil, the n-alkanes and branched alkanes could disappear completely, and PAHs and their alkyl homologues are likely to be highly degraded (Wang et al., 1994). Table 2 summarizes the TPH concentration in sediment after several oil accidents. A study on the Arrow oil spill after 46 years showed that surface oil declined at a logarithmic rate from 1970 to 1975 . The fastest natural attenuation was recorded at low tide on shores exposed to high wave energy, and the slowest was recorded at high tide in sheltered section. Nevertheless, the degradation rate of oil that deeply penetrated the subsurface was very slow (Yang et al., 2018). The Baffin Island Oil Spill (BIOS) project was carried out in the Arctic at a location where cold water and air temperatures prevailed throughout the study period. Residual stranded oil observed over the years following the experiment was either a hard pavement or sealed by ice; thus, attenuation rates were expected to be slow. Oil-degrading bacteria were observed in oiled sediments from the intertidal zone during the BIOS project and part of the oil reduction could be attributed to biodegradation (Wang et al., 1995; Owens et al., 2002).

When making decisions in response to a spill (prevention measures or restoration measures), more attention should be given to long-term effects rather than neglecting their implications. The total cost of an oil spill is the sum of both shortterm and long-term damage. Long-term damage to sensitive 
Table 2. TPH Concentration in Sediments after Oil Spill Accidents

\begin{tabular}{|c|c|c|c|c|c|}
\hline $\begin{array}{l}\text { Spill } \\
\text { accident }\end{array}$ & $\begin{array}{l}\text { Years after } \\
\text { spill }\end{array}$ & $\begin{array}{l}\text { Spilled oil } \\
\text { type }\end{array}$ & Sampling position & $\begin{array}{l}\text { TPH concentration } \\
(\mathrm{ppm})\end{array}$ & References \\
\hline \multirow{5}{*}{$\begin{array}{l}\text { BIOS } \\
\text { project }\end{array}$} & \multirow[t]{5}{*}{12} & \multirow[t]{5}{*}{ Crude oil } & Fine sediments with coarse fraction & 1.4 & \multirow{5}{*}{$\begin{array}{l}\text { (Wang et al., } \\
1995 \text { ) }\end{array}$} \\
\hline & & & Dry oily pebbles & 3,400 & \\
\hline & & & Black, sticky, oily pebbles $(2 \sim 5 \mathrm{~cm})$ & 7,400 & \\
\hline & & & Interstitial water from pit, some oil on water surface & 2,100 & \\
\hline & & & Mixture of oily granule and pebble & $>10,000$ & \\
\hline \multirow[t]{12}{*}{ Arrow } & \multirow[t]{12}{*}{22} & \multirow{12}{*}{$\begin{array}{l}\text { Bunker C } \\
\text { fuel }\end{array}$} & Weathered source oil & 450,000 & \multirow{12}{*}{$\begin{array}{l}\text { (Wang et al., } \\
\text { 1994) }\end{array}$} \\
\hline & & & Mid-intertidal zone, fine organic sediments & 33,300 & \\
\hline & & & Supratidal zone, sand substrate & 51,000 & \\
\hline & & & Upper intertidal zone, dry course sediment substrate & 47,500 & \\
\hline & & & Mid-intertidal zone, dry coarse sand & 33,100 & \\
\hline & & & Lower intertidal zone, fine silt sediments with eelgrass & 2,200 & \\
\hline & & & Supratidal zone, cobbles & 229,000 & \\
\hline & & & Upper intertidal zone, fine organic sediments, marsh grasses & 31,600 & \\
\hline & & & Mid to upper intertidal zone, sandy-cobble substrate & 12,800 & \\
\hline & & & $\begin{array}{l}\text { Upper intertidal zone, asphalt pavement, over sandy-cobble } \\
\text { very weathered in appearance }\end{array}$ & 9,000 & \\
\hline & & & Supratidal zone, oil cover on pebble-cobble beach & 500 & \\
\hline & & & Mid-intertidal zone, sheltered lagoon of fine silts/mud & 200 & \\
\hline \multirow[t]{4}{*}{ Arrow } & \multirow{4}{*}{$\begin{array}{l}45 \text { years in } \\
\text { tanker } 1 \\
\text { year after } \\
\text { post-spill }\end{array}$} & \multirow{4}{*}{$\begin{array}{l}\text { Bunker C } \\
\text { fuel }\end{array}$} & Mixed clay, sand, and pebble shoreline & $<10$ & \multirow{4}{*}{$\begin{array}{l}\text { (Yang et al., } \\
\text { 2018) }\end{array}$} \\
\hline & & & Mixed coarse sediment (pebble/cobble/boulder) & $14 \sim 411$ & \\
\hline & & & Oil crust on rocks, surface oil & $15,000 \sim 530,000$ & \\
\hline & & & Oil on rocks, oil under rocks, surface oil & $15,000 \sim 380,000$ & \\
\hline
\end{tabular}

habitats and living creatures require more consideration, even if it is difficult to evaluate compared to the relatively evident or acute issues.

\subsection{Field Oil Spill Experiments}

Shoreline field experiments are an efficient and reliable approach for facilitating our understanding of the ecological impacts of cleanup of contaminated habitats. Field experiments can assist in determining the threshold at which an oiled habitat should be left alone, the most effective timing of various treatments, and the optimal conditions under which a cleanup method will be effective without increasing adverse ecological impacts. It is hard to obtain such information from laboratory tests. To further advance our knowledge, field experiments are necessary to obtain timely answers to crucial and specific questions. The claim is that the impact is outweighed by the side effects of such studies (Baker et al., 1993).

In the fall of 1995, a pilot study was conducted on cobbles with attached biota obtained from a donor beach near the Bamfield Marine Station on Barkley Sound, British Columbia. The study aimed to identify the biological effects associated with the hydraulic cleaning variables of water pressure, temperature, and duration of application on intertidal biota, and to obtain data on the optimal combination of hydraulic cleaning parameters. The findings revealed that both mortalities and oil removal efficiencies increased between 40 and $60{ }^{\circ} \mathrm{C}$ and between 18.6 and $60 \mathrm{kPa}$ and that a 90-degree nozzle may cause more mortalities than a 45-degree nozzle (Mauseth, 1997).

Efforts funded by the MPRI program have, in part, been directed to provide decision makers with science-based evidence that in-situ treatment methods by sediment mixing or relocation have been proven to be effective and do not require large amounts of labor or logistics support and do not generate large volumes of waste. Much of this data is derived from the internationally-funded ITOSS field experiments led by Environment Canada in Svalbard, Norway (Sergy et al., 2003). Based on these and other data, the preferred strategy for oiled sediment beaches in remote regions is to consider in situ treatment methods. The second alternative is to allow the shoreline to recover naturally. However, the long-term fate and effects of a large oil spill on Arctic shorelines is not fully understood. A third option is manual or mechanical cleanup which requires substantial logistics support and which respectively are labor intensive and generate large volumes of waste.

Between May 1980 and August 1983 in Canada's eastern Arctic at Cape Hatt, on the northern end of Baffin Island, $45 \mathrm{~m}^{3}$ of medium gravity crude oil were released in a typical Canadian arctic shoreline environment. These field experiments aimed to test how the application of dispersants in the Arctic nearshore would modulate the environmental effects of spilled oil and to examine the effectiveness of a range of shoreline cleanup techniques. The second objective was to investigate the chemical and physical fate of oil in the Arctic nearshore and shoreline areas. The BIOS project was structured into two major experiments: a nearshore experiment that compared the consequences of dispersing oil and natural self-cleaning, and a shoreline experiment that compared the effectiveness of arctic shoreline cleanup techniques and natural self-cleaning. First, the results suggested no evident ecological reasons to restrict 
the use of dispersants in such nearshore environments. Second, the results did not offer strong ecological reasons for the removal of stranded oil on such shorelines. An opinion based on these results was that dispersants can be an option for nearshore intervention where the prevention of shoreline protects wildlife, critical habitat, or human use (Owens et al., 1982, 1984; Sergy, 1985).

A controlled oil spill experiment at a wetland at St. Croix, QC, investigated the toxicity of crude and refined oils to invertebrates. This study found that the mystery snail (Viviparus georgianus) and the mimic pondsnail (Pseudosuccinea columella) had different sensitivities due to their feeding habits. For instance, Viviparus georgianus (a detritivore) directly assimilated contaminants from sediments, whereas Pseudosuccinea columella was a herbivore that indirectly assimilated contaminants from oiled vegetation (Lee et al., 2000).

Salt marshes are productive communities of ecological and economic significance. The marsh surface is flooded with seawater twice per day and there is insufficient wave action to naturally physically remove the stranded oil. One potential approach to reduce the oil entering the salt marsh is to apply chemical dispersants. However, dispersant may contaminate and harm salt marsh vegetation. In July 1986, the impacts of treatment of salt marshes with Corexit 9527 were investigated at Conrod's Beach, Nova Scotia. This study suggested that the benefits of dispersant for a more rapid vegetation recovery were small. Dispersant and oil with dispersant may inhibit vegetation recovery due to acute toxicity. Oil alone lasted longer but had a lower acute toxicity, and when combined with mechanical measures, can increase the recovery rate (Lane and Funds, 1987; Crowell and Lane, 1988; MacKinnon, 1993).

\section{Conclusions}

A shoreline encompasses a diverse array of habitats and resources and is unique in respect of oil behavior and spill treatment. The analysis of historical case studies is important for future spill responses. This study summarized the oil spill accidents that impacted shorelines and analyzed the related information. Plans for the "Shoreline DST Historical Database" are to incorporate this information and data from experimental spills that involved shoreline cleanup and monitoring (BIOS, Svalbard, Conrods) and spills from temperate to arctic marine environments in which shoreline oiling and cleanup are well documented (Exxon Valdez, Selandang Ayu, and others). The addition of these other cases will broaden the utility of the Shoreline DST similarity chooser.

Our findings indicated that, in the past decades, the number of oil spill accidents with shoreline contact was relatively constant. However, in the past 10 years, more accidents have occurred impacting shorelines. Most of the accidents occurred on Canada's Pacific coast, accounting for $52 \%$ of the total accidents recorded. Atlantic coast accounted for 39\%, and the rest accidents occurred in the Arctic region. Up to $30 \%$ of the accidents spilled oil volumes smaller than $10 \mathrm{~m}^{3}$. Spilled volumes ranged between $10 \sim 100 \mathrm{~m}^{3}$ accounted for $25 \%$, and volumes ranged between $100 \sim 1000 \mathrm{~m}^{3}$ took a proportion of $30 \% .15 \%$ of the accidents had spilled volumes greater than $1000 \mathrm{~m}^{3}$. Within the oil spill accidents impacting shorelines, marine vessel accidents were the major sources accounting for $70 \%$ of the spills. The commonly employed treatments were manual, vacuum, mechanical, and sorbent cleanup.

It should be noted that the present study did not include inland freshwater spills. Although freshwater spills are prone to be smaller-scale than those in marine habitats, they can pose greater threats to the environment owing to the greater possibility of occurrence in populated regions close to water bodies with less dispersion and dilution capacity. Therefore, future studies can further take inland spills into consideration.

The reliability and accuracy of the dataset from oil spills and cleanup efforts largely depends on the quantity and quality of the reported data. Part of the cases recorded in the dataset analyzed in this study provided limited information about cleanup techniques, timelines, and results. More comprehensive data collection to include larger geographic range is also expected in the future study. A centralized database for spills and response to include location, timing, accident causes, spill information, environmental properties, treatment tactics, and monitoring data would be beneficial to contingency planning and future responders.

Acknowledgements. This research was supported by the Multi-partner Research Initiative of Fisheries and Oceans Canada.

\section{References}

Ages, A. (1971). Oil reconnaissance in the Magdalen islands-1970. Atlantic Oceanography Laboratory, Institutde Bedford, Rapport AOL 1971-1978. https://waves-vagues.dfo-mpo.gc.ca/Library/494 45.pdf.

Baker, J.M., Little, D.I. and Owens, E.H. (1993). A Review of Experimental Shoreline Oil Spills. International Oil Spill Conference Proceedings, 1993(1): 583-590. https://doi.org/10.7901/2169-3358 -1993-1-583

Barbier, E.B., Koch, E.W., Silliman, B.R., Hacker, S.D., Wolanski, E., Primavera, J., Granek, E.F., Polasky, S., Aswani, S., Cramer, L.A., Stoms, D.M., Kennedy, C.J., Bael, D., Kappel, C.V., Perillo, G.M.E. and Reed, D.J. (2008). Coastal ecosystem-based management with nonlinear ecological functions and values. Science, 319(5861): 321. https://doi.org/10.1126/science.1150349

BC government. (1988). Past Spill Incidents. https://www2.gov.bc.

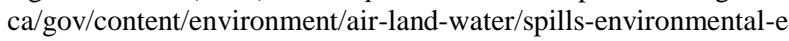
mergencies/spill-incidents/past-spill-incidents.

BC government. (2017). Diesel Spill South of Port McNeill. https:// www2.gov.bc.ca/gov/content/environment/air-land-water/spills-en vironmental-emergencies/spill-incidents/diesel-spill-south-of-portmoneill

Bradley, S. (2018). NSP continues cleanup after 5,000 litres of oil spilled into Halifax harbour. https://www.cbc.ca/news/canada/no va-scotia/clean-up-continues-oil-spill-tufts-cove-generating-plant1.4774896

Brown, C.E., Nelson, R.D. and Fingas, M.F. (1996). Recovery of the Irving Whale oil barge: Overflights with the laser environmental airborne fluorosensor. Spill Science \& Technology Bulletin, 3(4): 231-234. https://doi.org/10.1016/S1353-2561(97)00019-4

Challenger, G., Sergy, G. and Graham, A. (2008). Vegetation response 
and sediment polycyclic aromatic hydrocarbon attenuation in a Carex marsh in Howe Sound, British Columbia, Canada following a spill of Bunker $\mathrm{C}$ fuel oil. International Oil Spill Conference Proceedings 2008 (1): 847-854. https://doi.org/10.7901/2169-3358 $-2008-1-847$

Council of Canadian Academies (2017). The value of commercial marine shipping to Canada. https://cca-reports.ca/wp-content/up loads/2018/08/ValueMarineShipping_fullreport_EN.pdf.

Crowell, M.J. and Lane, P.A. (1988). Recovery of a Nova Scotian saltmarsh during two growing seasons following experimental spills of crude oil and the dispersant Corexit 9527. Proc. 11th Arctic and Marine Oil Spill Program Technical Seminar, Environment Canada, Ottawa ON, 89-127.

Cunha, I., Moreira, S. and Santos, M.M. (2015). Review on hazardous and noxious substances (HNS) involved in marine spill incidents-an online database. Journal of Hazardous Materials, 285: 509-516. https://doi.org/10.1016/j.jhazmat.2014.11.005

Duerden, F.C. and Swiss, J.J. (1981). Kurdistan-an unusual spill successfully handled. International Oil Spill Conference Proceedings, 1981(1): 215-219. https://doi.org/10.7901/2169-3358-1981-1-215

Environment and Climate Change Canada. (2016). A Field Guide to Oil Spill Response on Marine Shorelines. http://www.shorelinescat. com/Documents/Manuals/ECCC\%20Marine\%20Response\%20Fie ld\%20Guide\%20(1).pdf.

Gilfillan, E.S., Maher, N.P., Krejsa, C.M., Lanphear, M.E., Ball, C.D., Meltzer, J.B. and Page, D.S. (1995). Use of remote sensing to document changes in marsh vegetation following the Amoco Cadiz Oil Spill (Brittany, France, 1978). Marine Pollution Bulletin, 30(12): 780-787. https://doi.org/10.1016/0025-326X(95)00069-Y

Government of Canada. (2020). Pipelines across Canada. https://www. nrcan.gc.ca/our-natural-resources/energy-sources-distribution/clea n-fossil-fuels/pipelines/pipelines-across-canada/18856.

Helm, R.C., Costa, D.P., DeBruyn, T.D., O'Shea, T.J., Wells, R.S. and Williams, T.M. (2015). Overview of effects of oil spills on marine mammals. Handbook of Oil Spill Science and Technology. Fingas M., John Wiley and Sons: 455-475. https://doi.org/10.1002/97811 18989982.ch18

IPIECA (2016). Impacts of oil spills on shorelines. https://www.ipieca. org/resources/good-practice/impacts-of-oil-spills-on-shorelines/.

ITOPF. (2018). ODYSSEY, off Canada, 1988. https://www.itopf.org/ in-action/case-studies/case-study/odyssey-off-canada-1988/.

Kienholz, E., Canada, Lands, D. and Atlantic, R. (1982). The Kurdistan Incident: The Onshore Impacts of An Offshore Oil Spill. Lands Directorate, Atlantic Region, Environment Canada.

La Presse. (2014). Leak from an oil pipeline: a fault has been located. Retrieved. https://www.lapresse.ca/actualites/environnement/2014 09/18/01-4801512-fuite-dun-oleoduc-une-defaillance-a-ete-localis ee.php?utm_categorieinterne=trafficdrivers\&utm_contenuinterne $=$ cyberpresse_B9_environnement_263_accueil_POS2

Lane, P.A., Crowell, M.J., Patriquin, D.G. and Buist, I. (1987). Use of Chemical Dispersants in Salt Marshes, Environmental Studies Research Funds Report No. 070. Ottawa.

Lee, K., Wells, P.G. and Gordon, D.C. (2020). Reflecting on an anniversary. The 1970 SS Arrow oil spill in Chedabucto Bay, Nova Scotia, Canada. Marine Pollution Bulletin, 157: 111332. https://doi. org/10.1016/j.marpolbul.2020.111332

Lee, L.E.J., Stassen, J. and Lee, K. (2000). The mystery snail, Viviparus georgianus, as biomonitors of oil-spill and bioremediation strategies in fresh-water habitats. In: Proceedings of the 27th Annual Aquatic Toxicity.

Lee, M. and Jung, J.Y. (2013). Risk assessment and national measure plan for oil and HNS spill accidents near Korea. Marine Pollution Bulletin, 73(1): 339-344. https://doi.org/10.1016/j.marpolbul.2013. 05.021

Liquete, C., Piroddi, C., Drakou, E.G., Gurney, L., Katsanevakis, S., Charef, A. and Egoh, B. (2013). Current status and future prospects for the assessment of marine and coastal ecosystem services: A systematic review. Plos One, 8(7): e67737. https://doi.org/10.13 71/journal.pone.0067737

MacKinnon, D.L., PA. (1993). Saltmarsh revisited the long-term effects of oil and dispersant on saltmarsh vegetation. https://www. esrfunds.org/sites/www.esrfunds.org/files/publications/ESRF122MacKinnonLane.pdf.

Mauseth, G., Gerald, E., Brocco, S. and Sergy, G. (1997). Biological optimization of hydraulic cleaning of oiled coarse-sediment beaches: preliminary results. International Oil Spill Conference, 1: 271-275. https://doi.org/10.7901/2169-3358-1997-1-271

Morandin, L.A. and O'Hara, P.D. (2016). Offshore oil and gas, and operational sheen occurrence: is there potential harm to marine birds? Environmental Reviews, 24(3): 1-34. https://doi.org/10.1139/er-20 15-0086

National Research Council (2003). Oil in the sea III: inputs, fates, and effects. Washington, DC, The National Academies Press.

NOAA. (1970). Incident News. https://incidentnews.noaa.gov/inci dent/6208\#!

NOAA (2013). Oil spills in marshes planning and response considerations.https://response.restoration.noaa.gov/sites/default/files/Oil_S pills_in_Marshes.pdf.

Owens, E.H. (2010a). Shoreline response and long-term oil behaviour studies following the 1970 "Arrow" spill in Chedabucto Bay, NS. Proceedings of the 33rd Arctic and Marine Oilspill Programme (AMOP) Technical Seminar Environment Canada, Ottawa, ON: 207-222.

Owens, E., Sergy, G.A. and Prince, R. (2002). The fate of stranded oil at the BIOS site twenty years after the experiment. Environment Canada Arctic and Marine Oil Spill Program Technical Seminar (AMOP) Proceedings, 25: 1-11.

Owens, E.H. (1971). The Restoration of Beaches Contaminated by Oil in Chedabucto Bay, Nova Scotia, Marine Sciences Branch, Department of Energy, Mines and Resources, Ottawa.

Owens, E.H. (2010b). Response and Long-Term Oil Behaviour Studies following the 1970 "ARROW" Spill in Chedabucto Bay, NS. Proceedings 33rd Arctic and Marine Oilspill Programme (AMOP) Technical Seminar, Ottawa, ON, 207-221.

Owens, E.H., Dubach, H.C., Bunker, P., MacDonald, S., Yang, Z., Lambert, P. and LaForest, S. (2017). Canine Oil Detection (K9SCAT) following 2015 Releases from the T/V Arrow Wreck. International Oil Spill Conference Proceedings, 2017(1): 2620-2641. https://doi.org/10.7901/2169-3358-2017.1.2620

Owens, E.H., Foget, C.R. and Robson, W. (1984). Experimental Use of Dispersants for Spill Countermeasures on Arctic Beaches. In Oil Spill Chemical Dispersants: Research, Experience, and Recommendations, ASTM International: 324-337. https://doi.org/10.1520/STP 30244S

Owens, E.H., Humphrey, B. and Robson, W. (1982). Results of beach studies and chemical analyses from the BIOS experimental site and from the "Metula" spill site. Proc. 11th Arctic and Marine Oilspill Program (AMOP) Technical Seminar, Vancouver, B.C., Environment Canada, Ottawa, Ontario, 171-183.

Owens, E.H., Prince, R.C. and Taylor, R.B. (2008). Shoreline Observations and Sample Analysis Results from Black Duck Cove over 35 following the "Arrow" Oil Spill. Proc.31sth Arctic Marine Oilspill Program (AMOP) Technical Seminar, Environment Canada, Ottawa ON, 585-599.

Owens, E.H., Sergy, G.A., McGuire, B.E. and Humphrey, B. (1993). The 1970 Arrow oil spill: What remains on the shoreline 22 years later? http://inis.iaea.org/search/search.aspx?orig_q=RN:25063998.

Owens, E.H., Taylor, E., Gmur, S., C., A., Danner, G. and Lee, K. (2021). Shoreline response program (SRP) decision support tool based on the geographic variability in attenuation and weathering of oil stranded in Canadian marine coastal environments. Proc. International Oil Spill Conference. 
Owens, E.H., Taylor, E., O'Connell, K. and Smith, C. (2009). Waste management guidelines for remote (Arctic) regions. Environment Canada, Ottawa, ON (Canada)

Ramseier, R.O., Gantcheff, G.S. and Colby, L. (1973). Oil spill at Deception Bay, Hudson Strait. Environment Canada, Inland Waters Directorate, Scientific Series. 29: 60.

Sergy, G.A. (1985). The Baffin Island oil spill (BIOS) project: a summary. Oil Spill Conference, 1: 571-575. https://doi.org/10.7901/ 2169-3358-1985-1-571

Sergy, G.A., Guénette, C.C., Owens, E.H., Prince, R.C. and Lee, K. (2003). In-situ treatment of oiled sediment shorelines. Spill Science \& Technology Bulletin, 8(3): 237-244. https://doi.org/10.1016/S135 3-2561(03)00040-9

Taylor, R.B. and Frobel, D. (1985). Coastal oiling studies - Beach reconnaissance od S.E. Cape Breton Ilsnad in support of oilspill cleanup operations.

The Ministry of Transport (1970). Report of the scientific coordination team to the head of the task force operation oil (the Arrow incident). Retrieved.

Trans Mountain. (2007). Westridge 2007 Spill. https://www.trans mountain.com/westridge-2007-spill.

Venosa, A.D., Lee, K., Suidan, M.T., Garcia-Blanco, S., Cobanli, S.,
Moteleb, M., Haines, J.R., Tremblay, G. and Hazelwood, M. (2002). Bioremediation and biorestoration of a crube oil-contaminated freshwater wetland on the St. Lawrence River. Bioremediation Journal, 6(3): 261-281. https://doi.org/10.1080/10889860290777602

Wang, Z., An, C.J., Lee, K., Owens, E., Chen, Z., Boufadel, M., Taylor, E. and Feng, Q. (2020). Factors influencing the fate of oil spilled on shorelines: A review. Environmental Chemistry Letters. https://doi. org/10.1007/s10311-020-01097-4

Wang, Z., Fingas, M. and Sergy, G. (1994). Study of 22-year-old arrow oil samples using biomarker compounds by GC/MS. Environmental Science \& Technology, 28(9): 1733-1746. https://doi.org/10.1021/ es00058a027

Wang, Z., Fingas, M. and Sergy, G. (1995). Chemical characterization of crude oil residues from an arctic beach by GC/MS and GC/FID. Environmental Science \& Technology, 29(10): 2622-2631. https:// doi.org/10.1021/es00010a025

Yang, Z., Shah, K., Laforest, S., Hollebone, B.P., Lambert, P., Brown, C.E., Yang, C. and Goldthorp, M. (2018). A study of the 46-yearold Arrow oil spill: Persistence of oil residues and variability in oil contamination along Chedabucto Bay, Nova Scotia, Canada. Journal of Cleaner Production, 198: 1459-147 https://doi.org/10.1016 /j.jclepro.2018.07.112 